\title{
Quart Dry US
}

National Cancer Institute

\section{Source}

National Cancer Institute. Quart Dry US. NCI Thesaurus. Code C69118.

A unit of volume in US customary measure system for dry volumes equal to 67.201 cubic inches, or approximately 1.101221 liters. 